\title{
Removal of Cadmium(II) and Lead(II) Ions from Aqueous Phase on Sodic Bentonite
}

\author{
Luz, Stella Gaona Galindo, Ambrósio Florêncio de Almeida Neto*, \\ Meuris Gurgel Carlos da Silva, Melissa Gurgel Adeodato Vieira
}

\author{
Department of Processes and Products Design - DDPP, School of Chemical Engineering - FEQ, \\ University of Campinas - UNICAMP, Cidade Universitária "Zeferino Vaz", \\ CEP 13083-852, Campinas, SP, Brazil
}

Received: June 21, 2012; Revised: November 20, 2012

\begin{abstract}
This paper describes the adsorption of $\mathrm{Cd}^{2+}$ and $\mathrm{Pb}^{2+}$ ions using sodic bentonite clay type Fluidgel modified. The Fluidgel before and after chemical modification and thermal activation was characterized by different techniques including X-ray diffraction, thermal analysis, Fourier transform infrared, surface area, helium pycnometry, cation exchange capacity and scanning electron microscopy. Pseudo-first order, pseudo-second order and intra-particle diffusion models were used to analyze the kinetic curves. Equilibrium data were analyzed using Langmuir and Freundlich models. The thermodynamic study indicated that lead adsorption process is endothermic and interactions between clays and solutions of lead occurred spontaneously, while cadmium adsorption revealed an exothermic and spontaneous nature. The maximum removal efficiencies were $97.62 \%$ for $\mathrm{Cd}$ (II) using Fluidgel modified chemically and $91.08 \%$ for lead by Fluidgel modified chemical and thermally.
\end{abstract}

Keywords: adsorption, bentonite clay, lead, cadmium

\section{Introduction}

The increment of human wastes mainly caused by industries, due to the constant discharge of pollutants, contributes to declining water quality. Metal species from industrial waste are the most problematic pollutants that affect the biological function of many organisms, reducing the self-purification capacity of water, interfering with the metabolic cycle and causing an increase in the concentration of metals along the food chain.

Heavy metals are a great concern in the environmental area and also in the area of public health. Cadmium is bio-persistent and once absorbed, it remains resident for long time in the kidneys and liver, causing severe damage to these organs. Lead is one of the most dangerous pollutants; even at low concentrations is extremely toxic, causing brain damage in children ${ }^{1}$.

Traditional processes have been used for treating effluents that contain heavy metals, they include: ion exchange $^{2}$, reverse osmosis ${ }^{3}$, chemical coagulation and precipitation $^{4}$, ultrafiltration ${ }^{5}$, and adsorption ${ }^{6}$. The latter is one of the most effective and economical techniques used to remove heavy metals ${ }^{7}$. Different adsorbents have been employed in the process of adsorption: activated charcoal $^{8}$, kaolinite ${ }^{9}$, natural and synthetic zeolites ${ }^{10}$, rice husks ${ }^{11}$, clays ${ }^{12}$, among others. Clays have properties such as high cation exchange capacity, they are easily available and low cost adsorbents, which can be recycled and reused for subsequent cycles. Bentonites are highly efficient in adsorption of heavy metals ${ }^{13}$.

*e-mail: ambrosio@ feq.unicamp.br
The atomic structure of bentonite clay is composed of montmorillonite, which is a 2:1 type aluminosilicate. The inner layer is composed by an octahedral sheet located between two tetrahedral sheets. The octahedral sheet is composed of oxygen atoms, which are present in a compact form and aluminum, iron and magnesium atoms arranged. The second structural unit is the layer of tetrahedral silica in which the silicon atom is equidistant from four oxygen atoms ${ }^{14}$. Substitutions inside the lattice structure of trivalent aluminium for quadrivalent silicon in the tetrahedral sheet and of ions of lower valence, particularly magnesium, for trivalent aluminium in the octahedral sheet are responsible for the appearance of an electric charge, which is usually negative on the clay surfaces. The negative charges on the surface of the crystals attract cations and this process is known as ion exchange and confers important properties to clays in industrial applications ${ }^{15}$.

Several studies have been developed using bentonite clay as adsorbent of heavy metals: Almeida et al. ${ }^{16}$ evaluated the removal of copper using bentonite clay, achieving around $81 \%$ of efficiency using raw clays and $42 \%$ by calcined bentonite clays. Bertagnolli et al. ${ }^{17}$ used Brazilian bentonite clay for adsorption of copper in porous beds, obtaining 50\% of the removal percentage. Karapinar and Bonatb ${ }^{18}$ studied the adsorption process of copper and cadmium, the results showed that the maximum removal efficiencies for $\mathrm{Cu}^{2+}$ and $\mathrm{Cd}^{2+}$ onto natural bentonite were 84.49 and $87.02 \%$, respectively and Inglezakisa ${ }^{19}$ reached $100 \%$ of efficiency in the removal of $\mathrm{Pb}$ (II) form aqueous solutions using clinoptilolite and bentonite as adsorvents. 
The reserves of smectite clays such as Fluidgel clay in the city of Boa Vista - PB (Brazil) represent a major national source of clays that are used for perforating fluid. In this context, the aim of this research was to evaluate an additional use of this clay such as alternative adsorbent for removing metal ions in aqueous solution.

The suitable design of adsorption processes determines the efficiency of the treatment techniques. Batch experiments are commonly used in laboratory to evaluate the treatment of small volumes of effluents, providing preliminaries information based on the kinetics and the thermodynamics studies, which are helpful for selecting optimum operating conditions for the full-scale batch and fixed bed process. Previous researchers have reported the kinetics and thermodynamics studies of the adsorption of $\mathrm{Cd}^{2+}$ and $\mathrm{Pb}^{2+}$ on clays; $\mathrm{Cd}^{2+}$ on $\mathrm{HACC}$-benonite ${ }^{20} ; \mathrm{Pb}^{2+}$ onto Turkish kaolinite clay ${ }^{21}$; $\mathrm{Cd}^{2+}$ and $\mathrm{Pb}^{2+}$ ions on tripolyphosphate-modified kaolinite clay ${ }^{22}$ and removal of $\mathrm{Pb}^{2+}$ ions by phosphatic clay ${ }^{23}$.

In this study, Fluidgel clay was treated with acid with the purpose to remove its carbonates and additionally a heat treatment was performed in order to improve their physical stability. The aim of this paper was to analyze the removal of cadmium and lead onto acid-treated Fluidgel bentonite clay and Fluidgel modified chemical and thermally bentonite clay. Kinetic parameters were calculated to determine the sorption mechanisms and potential rate-controlling steps, such as external and intra-particle mass transfer involved in the adsorption processes of cadmium and lead ions. Adsorption isotherms, including Langmuir and Freundlich isotherms were applied to the equilibrium data with the objective to describe the principal interactive mechanisms involved in the removal processes.

\section{Material and Methods}

\subsection{Sodic bentonite clay: Fluidgel}

The sodic bentonite clay was obtained from Boa Vista, Paraíba, located in the northeastern region of Brazil. Fluidgel is composed of natural clay with sodium carbonate addition. The material was subjected to acid treatment, with the purpose to remove carbonates, because the $\mathrm{pH}$ of the Fluidgel occasioned chemical precipitation. In order to improve the physical stability, it was also carried out a thermal treatment; the calcination temperature was defined from thermogravimetric analysis.

\subsection{Preparation and methods of analysis of materials}

Fluidgel clay was ground and classified to obtain a size range of $(0.855 \mathrm{~mm})$ suitable for the sorption tests.

Chemically treated clay: The preparation of the Fluidgel TA-bentonite was done for the removal of carbonates, then $100 \mathrm{~g}$ of Fluidgel clay was treated using $1000 \mathrm{~mL}$ of acetic acid solution (4\%), and the suspension was stirred at $1300 \mathrm{rpm}$ for 4 hours. After this, the suspension was filtered and the residue was washed thoroughly with $4 \mathrm{~L}$ of deionized water. The residue was dried at $60^{\circ} \mathrm{C}$ for 24 hours. This clay was named Fluidgel TA-bentonite.
Thermally treated clay: The Fluidgel TA-bentonite clay additionally was thermally activated at $750{ }^{\circ} \mathrm{C}$ for 24 hours after the chemical treatment to improve their physical stability and this clay was named as Fluidgel TACal-bentonite.

\subsection{Adsorbate solutions}

The adsorption study was performed using synthetic effluents containing $\mathrm{Cd}^{2+}$ and $\mathrm{Pb}^{2+}$ separately. Aqueous solutions were prepared by dissolving $\mathrm{Cd}\left(\mathrm{NO}_{3}\right)_{2} \cdot 4 \mathrm{H}_{2} \mathrm{O}$ and $\mathrm{Pb}\left(\mathrm{NO}_{3}\right)_{2}$, respectively, in deionizer water to desired concentrations. The $\mathrm{pH}$ study was performed through Hydra Medusa Chemical Diagrams software to determine the predominant chemical species of $\mathrm{Cd}(\mathrm{II})$ and $\mathrm{Pb}$ (II) and by the isoelectric point or $\mathrm{pH}$ of zero of charge $\left(\mathrm{pH}_{\mathrm{ZPC}}\right)$. The $\mathrm{pH}$ was adjusted by using $0.1 \mathrm{M} \mathrm{HNO}_{3}$. Cadmium and lead concentrations were determined using a PerkinElmer ANALYST-100 atomic absorption spectrophotometer.

\subsection{Clay characterization}

The adsorbents, named as Fluidgel, Fluidgel TA-bentonite and Fluidgel TACal-bentonite composite, were characterized using the following techniques such as:

X-ray diffraction: The XRD patterns of the samples were obtained using a Philips X`PERT X-ray diffractometer instrument with filtered $\mathrm{Cu} \mathrm{K} \alpha$ radiation, voltage $40 \mathrm{kV}$, $40 \mathrm{~mA}$, step size of 0.02 and time per step of 1.0 seconds.

Thermal analysis: The thermogravimetric and the differential scanning calorimetric analysis were performed using Shimadzu thermal analyzer in the following conditions: flow rate of $50 \mathrm{~mL} / \mathrm{min}$ of $\mathrm{N}_{2}$, heating rate $10^{\circ} \mathrm{C} / \mathrm{min}$ and temperature range from room temperature to $1000^{\circ} \mathrm{C}$ and $500{ }^{\circ} \mathrm{C}$ for TG and DSC analysis, respectively.

Scanning Electron Microscopy (SEM) coupled with the energy dispersive system (EDX): Samples were previously covered with gold. Scanning electron microscopy (SEM) was performed using a LEO 4410 . The acceleration voltage of the instrument ranged from $300 \mathrm{~V}$ to $30 \mathrm{kV}$, with an image point resolution of $10 \mathrm{~nm}$, with the magnification ranging between $30 \times$ to $300.000 \times$.

FTIR spectroscopy analysis: Spectra were obtained on the (Spectrum One-FT-IR, Perkin Elmer). The FT-IR spectra of the samples pressed into $\mathrm{KBr}$ pellets were collected in the wave number range of $4000-400 \mathrm{~cm}^{-1}$.

Helium pycnometry: experiments were developed using a Micromeritics, model AccuPyc 1330 gas pycnometer using helium. The analyses were carried out at $28{ }^{\circ} \mathrm{C}$ and $0.0010 \mathrm{psig} / \mathrm{min}$ equilibrium rates.

Surface area: The surface area was performed in a Micromeritics Gemini III 2375 Surface Area Analyzer device using the BET method with an average particle diameter of $0.855 \mathrm{~mm}$.

Cation exchange capacity (CEC): The CEC was determined by using ammonium acetate and was expressed in mEq. $(100 \mathrm{~g})^{-1}$ of $\mathrm{clay}^{24}$, according to Equation 1:

$$
C E C=\frac{C_{N a}^{+} \cdot V}{10 \cdot m \cdot f}
$$

Where $\mathrm{C}_{\mathrm{Na}}{ }^{+}$is the $\mathrm{Na}^{+}$concentration measured by atomic adsorption $\left(\mathrm{mg} . \mathrm{L}^{-1}\right), V(\mathrm{~mL})$ is the volume of $3 \mathrm{M}$ 
ammonium acetate, $\mathrm{m}$ is the sample mass ( $\mathrm{g}$ ) and $f$ is the conversion factor of sodium to equivalents $=23 \mathrm{~g}$ of sodium by equivalents.

In the estimative of CEC method only was considered the cation $\mathrm{Na}^{+}$, in view of the fact that this clay was chemically modified with sodium carbonate, being the $\mathrm{Na}^{+}$the main exchangeable cation. This method is widely used in the scientific literature ${ }^{24}$. Indeed, other cations such as $\mathrm{K}^{+}, \mathrm{Ca}^{2+}$ or $\mathrm{Mg}^{2+}$ present in the clay may also act as exchangeable cations, consequently the CEC estimated by this method may have been underestimated. The cation exchange capacity can be also estimated by using methylene blue adsorption; however, this colorimetric method may also present inaccurate results.

\subsection{Adsorption study}

The kinetic tests for the two metallic ions utilizing Fluidgel TA-bentonite and Fluidgel TACal-bentonite were performed at room temperature $\left(20^{\circ} \mathrm{C}\right)$ under constant agitation (250 rpm).

Adsorption experiments were carried out by mixing known amounts of clay adsorbents (20 g) with $2000 \mathrm{~mL}$ at $0.394 \mathrm{mmol} . \mathrm{L}^{-1}$ concentration of each aqueous solution containing $\mathrm{Cd}^{2+}$ and $\mathrm{Pb}^{2+}$ ions, respectively. Samples were withdrawn from the shaker at different time intervals; and were centrifuged for 10 minutes. The amount of metal ion adsorbed on the adsorbent (q) was calculated by Equation 2.

$$
q(t)=(V(C o-C(t))) / m
$$

where $\mathrm{q}$ is adsorbed amount ( $\mathrm{mmol}$ metal/g clay), $V$ is the solution volume $(\mathrm{mL}), C_{0}$ is the initial concentration metal ion $\left(\mathrm{mmol} . \mathrm{L}^{-1}\right), \mathrm{C}(\mathrm{t})\left(\mathrm{mmol} . \mathrm{L}^{-1}\right)$ is the concentration of metal ion in solution at time $\mathrm{t}$ (minutes) and $\mathrm{m}$ the mass of clay adsorbent $(\mathrm{g})$.

\subsubsection{Adsorption kinetic models}

The well-known pseudo-first order, pseudo-second order and intra-particle diffusion kinetic models were applied to experimental data with the purpose of evaluating the adsorption process. In cases where the resistance to mass transfer in the solid is dominant, the removal rate is represented by the following Equation 3:

$\frac{\partial q}{\partial t}=k_{1}\left(q_{e}-q\right)$

where $\mathrm{q}_{\mathrm{e}}$, is the amount of metal sorbed at equilibrium $\left(\mathrm{mmol} . \mathrm{g}^{-1}\right)$ and $\mathrm{k}_{1}$ is the adsorption rate constant $\left(\mathrm{min}^{-1}\right)$.

After integration and applying boundary condition $t=0$ to $\mathrm{t}=\mathrm{t}$ and $\mathrm{q}=0$ to $\mathrm{q}=\mathrm{qt}$, is obtained the Equation 4:

$\operatorname{In}\left(q_{e}-q\right)=\operatorname{In}\left(q_{e}\right)-k_{1} t$

The pseudo-second-order model is expressed by Equation 5:

$\frac{t}{q}=\frac{1}{k_{2} q_{e}^{2}}+\frac{1}{q_{e}} t$ where $k_{2} q_{e}^{2}$ that can be defined as the initial sorption rate when $\mathrm{t} \rightarrow 0$. The plot $\mathrm{t} / \mathrm{q}_{\mathrm{e}}$ versus $\mathrm{t}$ graph gives a linear relationship that allows computation of $\mathrm{q}_{\mathrm{e}}$ and $\mathrm{k}_{2}$.

When there is possibility for diffusing the adsorbate species into the adsorbent pores, the intraparticle diffusion rate constant $\left(\mathrm{k}_{\mathrm{i}}\right)$ can be obtained from Equation 6:

$q=k_{i} t^{\frac{1}{2}}+c$

In this case, the intraparticle diffusion has a significant effect on the control of the adsorption process kinetics. The $\mathrm{q}_{\mathrm{t}}$ versus $\mathrm{t}^{1 / 2}$ graph provides a straight line passing by the $\mathrm{y}$ axis with an inclination equal to the value of $\mathrm{k}_{\mathrm{i}}$. The values for $\mathrm{c}$ provide an approximation of the boundary layer thickness, the greater the $\mathrm{c}$ value, the greater the boundary layer effect is the deviation of the straight line from the origin may be attributed to a difference in mass transfer between the initial and final adsorption stages.

The coefficient of determination, $\mathrm{R}^{2}$, was determined using additionally others statistical parameters such as reduced chi-square $\left(\mathrm{X}^{2}\right)$ and root mean square error $\left(\mathrm{E}_{\mathrm{RMS}}\right)$ values, according to Equations 7 and 8.

$X^{2}=\frac{\sum_{i=1}^{N}\left(q_{e x, i}-q_{p r e, i}\right)^{2}}{N-Z}$

$E_{R M S}\left[\frac{1}{N} \sum_{i=1}^{N}(q e x, i-q p r e, i)^{2}\right]^{\frac{1}{2}}$

\subsection{Adsorption isotherm}

Adsorption isotherms were obtained at temperatures of 273, 293, 313 and 333 K. 0.5 g of clay Fluidgel TA-bentonite and Fluidgel TACal-bentonite, respectively, were put into Erlenmeyer flasks, each of them filled with $50 \mathrm{~mL}$ heavy metal solution at different concentrations (2 to $500 \mathrm{ppm}$ ). The time of the experiments was determined from the kinetic test and the $\mathrm{pH}$ of the solutions of $\mathrm{Cd}^{2+}$ and $\mathrm{Pb}^{2+}$ was adjusted at around 8 for $\mathrm{Cd}^{2+}$ and 5.2 for $\mathrm{Pb}^{2+}$ using nitric acid $0.1 \mathrm{M}$.

\subsubsection{Isotherm models}

With the purpose to establish the relationship between the amount of adsorbed metal onto Fluidgel TA-bentonite and Fluidgel TACal-bentonite and its equilibrium concentration in aqueous system, Langmuir and Freundlich isotherm models were used to fit the experimental data.

\section{Langmuir isotherm}

The model of Langmuir (1918) was originally developed assuming monolayer adsorption on a surface of the adsorbent with a finite number of adsorption sites.

The Langmuir equation is expressed by Equation 9:

$q=\frac{q_{\max b C e}}{1+b C e}$

where $C_{e}$ is the concentration of the adsorbate at equilibrium in the liquid phase $\left(\mathrm{mmol} . \mathrm{L}^{-1}\right)$ and $q$ is the concentration of the adsorbate in the solid phase $\left(\mathrm{mmol}_{\mathrm{g}} \mathrm{g}^{-1}\right), \mathrm{b}\left(\mathrm{L}_{\mathrm{g}} \mathrm{g}^{-1}\right)$ and $\mathrm{q}_{\max }$ 
(mmol. $\mathrm{g}^{-1}$ ) are Langmuir constant related of the adsorbateadsorbent equilibrium and the maximum adsorbed amount on the monolayer, respectively.

The essential characteristics of Langmuir isotherm model is explained in terms of a dimensionless constant separation factor or equilibrium parameter $R_{L}$, which is defined in Equation 10:

$$
R_{L}=\frac{1}{1+K_{L} C_{0}}
$$


the initial $\mathrm{Cd}(\mathrm{II})$ and $\mathrm{Pb}$ (II) ions concentration (mmol. $\mathrm{L}^{-1}$ ). The parameter $\mathrm{R}_{\mathrm{L}}$ indicates the curvature of the sorption isotherm: if $0<\mathrm{R}_{\mathrm{L}}<1$, the adsorption is favorable.

\section{Freundlich isotherm}

The Freundlich model assumes that adsorption takes place on heterogeneous surfaces of an adsorbent. Equation 11 represents this model.

$q=K C e^{n}$

where $\mathrm{K}$ and $\mathrm{n}$ are Freundlich coefficients.

\section{Thermodynamic parameters}

Thermodynamic parameters for the adsorption process $\Delta \mathrm{G}\left(\mathrm{J} . \mathrm{mol}^{-1}\right), \Delta \mathrm{H}\left(\mathrm{kJ} . \mathrm{mol}^{-1}\right)$ and $\Delta \mathrm{S}\left(\mathrm{J} . \mathrm{mol}^{-1} \cdot \mathrm{K}^{-1}\right)$ are calculated by Equations 12 and 13 .

$$
\operatorname{In} K=-\frac{\Delta H}{R T}+\frac{\Delta S}{R}
$$

$\Delta G=\Delta H-T \Delta s$

where $\Delta \mathrm{H}$ is the enthalpy, $\Delta \mathrm{S}$ is the entropy and $\Delta \mathrm{G}$ Gibbs free energy. $\mathrm{R}$ is the gas constant. The plots of $\ln K$ versus $1 / T$ provide the values of $\Delta \mathrm{H}$ and $\Delta \mathrm{S}$. The variation in Gibbs free energy $(\Delta G)$ is the fundamental criterion of process spontaneity.

\section{Results and Discussion}

\subsection{The XRD study}

Fluidgel, Fluidgel TA-bentonite and Fluidgel TACalbentonite are presented in Figure 1. The acid treatment caused structural changes in the samples; similar results were reported by other works ${ }^{25,26}$. The diffractograms show the presence of the characteristic peaks of montmorillonite and quartz. The result of the XRD analysis for basal spacing characteristic peaks $\left(\mathrm{d}_{001}\right)$ for Fluidgel was $1.483 \mathrm{~nm}$, which is a characteristic of the presence of divalent cations ${ }^{27}$.

The peak $\left(\mathrm{d}_{001}\right)$ expanded to $1.821 \mathrm{~nm}$ after the sample was treated with acid, indicating that the expandable layers of smectite type continue being predominant, this increase can be related to the presence of the acetic acid dissociated between the structural sheets. The decrease in the basal spacing to $1.130 \mathrm{~nm}$ indicates alterations in the interlayer of the clay layers after calcination at $750{ }^{\circ} \mathrm{C}^{28}$. X-ray diffraction results showed the presence of other peaks in the ranges: $0.45 \mathrm{~nm}$ (corresponding to the smectite clay mineral) and the additional peaks of quartz prevailing at 0.32 and $0.25 \mathrm{~nm}$.

The basal spacing characteristic peaks $\left(\mathrm{d}_{060}\right)$ is an important feature used for identifying the type of smectites and is located at $0.15 \mathrm{~nm}$, indicating that the smectite clay mineral is dioctahedral ${ }^{29}$. The samples showed the presence of sodium bicarbonate in the region of $0.34 \mathrm{~nm}$ corresponding to basal distance $(2 \Theta=29.58)$, which was not detected neither for Fluidgel TA-bentonite nor Fluidgel TACal-bentonite.

\subsection{Thermogravimetric analysis}

The thermal analysis diagrams for Fluidgel and Fluidgel TA-bentonite clay are shown in Figure 2. The corresponding weight loss for Fluidgel and Fluidgel TA-bentonite were 19.64 and $16.3 \%$ respectively.

Results showed an endothermic peak in the DTA curve of Fluidgel (Figure 2a) in the range of $25^{\circ} \mathrm{C}$ to $130{ }^{\circ} \mathrm{C}$ due to the dehydration of clay minerals. The second endothermic phenomenon took place between 350 and $600{ }^{\circ} \mathrm{C}$, this peak is referring to the loss of hydroxyl in the structure ${ }^{30}$. The corresponding loss of bicarbonates and carbonates are related to the endothermic peak around $283^{\circ} \mathrm{C}$ and $702{ }^{\circ} \mathrm{C}$, respectively.

The thermogravimetric results for Fluidgel TA-bentonite clay (Figure 2b) revealed a weight loss corresponding to free and absorbed water on the outer surface of bentonite and organic materials originating from acetate, due to acid treatment in the range of 34 to $133{ }^{\circ} \mathrm{C}$. The second peak occurring between 397 to $536{ }^{\circ} \mathrm{C}$ refers to the loss of hydroxyl in the structure.

\subsection{Physical properties of the Fluidgel clays}

The results obtained for the specific surface areas according to the BET method besides other physical properties are shown in Table 1. Considering BET adsorption isotherms, the micropores $\left(\mathrm{V}_{\mathrm{mi}}\right)$ and the mesopores $\left(\mathrm{V}_{\text {mes }}\right)$ volumes are obtained through the reading of adsorbed volume $\left(\mathrm{V}_{\mathrm{ads}}\right)$ in $\mathrm{P} / \mathrm{P}_{0}=0.10$ and 0.95 expressed by Equations 14 and 15.

$\mathrm{V}_{\mathrm{mi}}=\mathrm{V}_{\mathrm{ads}}\left(\mathrm{P} / \mathrm{P}_{0}=0.10\right)$

$\mathrm{V}_{\text {mes }=} \mathrm{V}_{\mathrm{ads}}\left(\mathrm{P} / \mathrm{P}_{0}=0.95\right)-\mathrm{V}_{\mathrm{ads}}\left(\mathrm{P} / \mathrm{P}_{0}=0.10\right)$

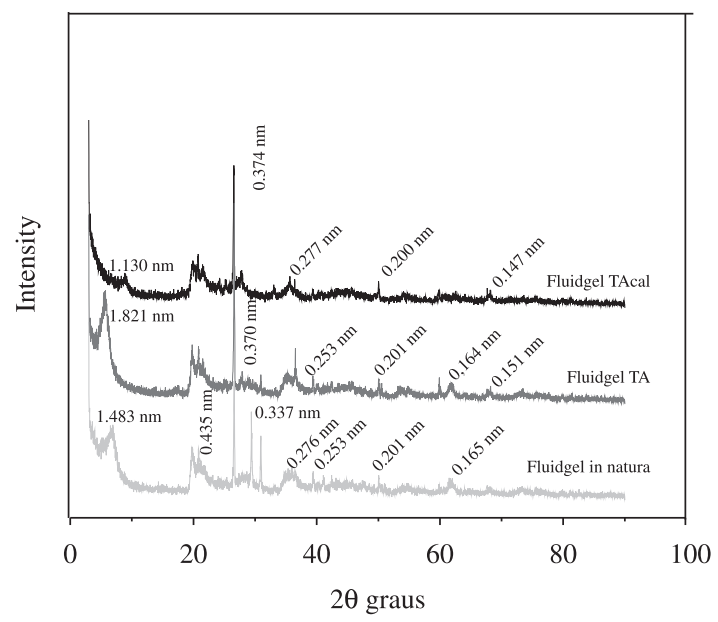

Figure 1. XDR patterns for Fluidge l-Fluidgel TA-bentonite and Fluidgel TACal-bentonite. 
The specific area of Fluidgel was found to be $57.60 \mathrm{~m}^{2} \cdot \mathrm{g}^{-1}$, this value is in agreement with those reported in the literature ${ }^{31}$, i.e. $53.6 \mathrm{~m}^{2} \cdot \mathrm{g}^{-1}$.

\subsection{Scanning electron micrograph (SEM)}

The morphologic analysis of three types of clay particles by scanning electron microscopy provided the micrograph shown in Figure 3. The SEM micrographs indicated macropores in the Fluidgel clay (Figure 3a) that were not evident in the modified clays (Figure $3 b$ ) whereas the Fluidgel TACal (Figure 3c) showed breaks in their particles.

The semi-quantitative chemical composition of the compounds for the Fluidgel clay and treated clays are shown in Table 2. The increase in silicon content for the modified clay is due to remobilization of octahedral cations ${ }^{32}$, which are removed into the solution while the silicon remained and increased its content due to it insolubility in acid solution ${ }^{33}$.

Table 1. Samples surface area calculated by the BET method and real density of Fluidgel, Fluidgel TA-bentonite and Fluidgel TACal-bentonite.

\begin{tabular}{ccccc}
\hline Clay & $\begin{array}{c}\mathbf{S}_{\text {BET }} \\
(\mathbf{g . m})\end{array}$ & $\begin{array}{c}\mathbf{V}_{\text {mi }} \\
(\mathbf{g . c m})\end{array}$ & $\begin{array}{c}\mathbf{V}_{\text {mes }} \\
\left(\mathbf{g . c m}^{-3}\right)\end{array}$ & $\begin{array}{c}\text { Real } \\
\text { density } \\
\left(\mathbf{g . c m}^{-3}\right)\end{array}$ \\
\hline Fluidgel & 57.60 & 14.99 & 13.18 & 2.49 \\
$\begin{array}{c}\text { Fluidgel TA } \\
\text { Fluidgel } \\
\text { TACal }\end{array}$ & 11.51 & 2.64 & 4.25 & 2.39 \\
\hline
\end{tabular}

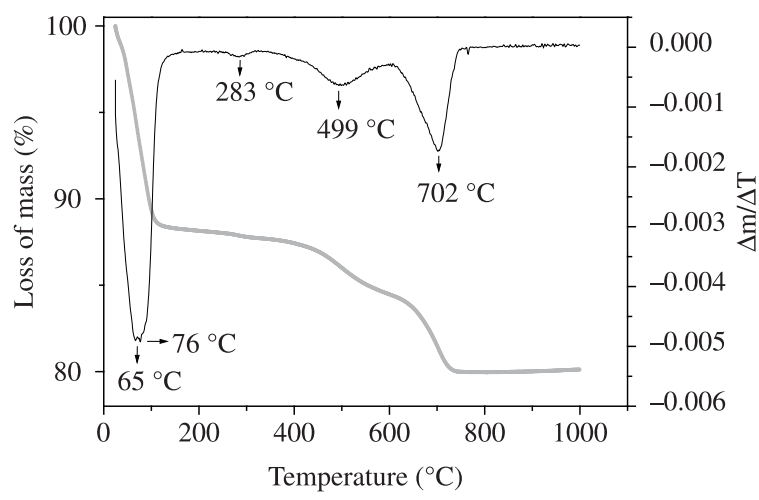

(a)
The results show that exchangeable cations $\left(\mathrm{Na}^{+}, \mathrm{Ca}^{2+}\right.$, $\mathrm{K}^{+}$) were reduced, which was caused by cation exchange of $\mathrm{H}^{+}$ions ${ }^{34}$. The structural formula for natural clay was calculated according to the method described by Souza Santos $^{35}$. The structural formula obtained for Fluidgel bentonite clay was $\left(\mathrm{Al}_{1.02} \mathrm{Fe}_{0.69} \mathrm{Mg}_{0.47}\right)_{\mathrm{IV}}\left(\mathrm{Si}_{3.72} \mathrm{Al}_{0.27}\right)_{\mathrm{IV}}$ $\mathrm{O}_{10}(\mathrm{OH})_{2}(\mathrm{Ca}, \mathrm{Na}, \mathrm{K})_{1.404}$, presenting chemical compositions reported for clays originating from northeast of Brazil ${ }^{35}$.

The levels of $\mathrm{Mg}, \mathrm{Fe}$ and others elements presented little changes, which can be attributed to the type of analysis, given that the technique of EDX detects the semi-quantitative chemical composition of the compounds point to point on the surface of the adsorbent.

\subsection{Fourier transform infrared spectroscopy}

Figure 4 shows the FTIR spectra of the Fluidgel samples as well as their respective treated samples. The presence of asymmetric stretching vibration of $\mathrm{Si}-\mathrm{O}$ were found at 1000 to $1042 \mathrm{~cm}^{-1}$, the stretching vibrations of $\mathrm{Al}-\mathrm{OH}$ and deformation of the water $\mathrm{H}-\mathrm{O}-\mathrm{H}$ occurring at 916 and $1645 \mathrm{~cm}^{-1}$. The other vibration at 796 and $524 \mathrm{~cm}^{-1}$ are attributable to vibration Si-O-Al. The stretching bands near $3650 \mathrm{~cm}^{-1}$ are characteristics of $\mathrm{OH}$ group and the presence of octahedral layers in the range of $\left(920 \mathrm{~cm}^{-1}, 800\right.$ and $\left.525 \mathrm{~cm}^{-1}\right)^{36}$.

\subsection{Estimation of cation exchange capacity (CEC)}

The Fluidgel commercial clay was treated with sodium carbonate, presenting a large excess of this salt. Thus,

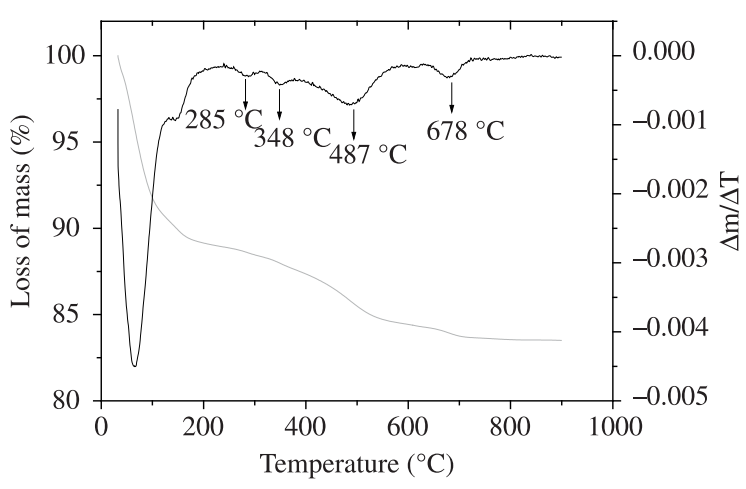

(b)

Figure 2. TG and DTG curves of (a) Fluidgel and (b) Fluidgel TA-bentoniteclays.

Table 2. Chemical analysis of the clays.

\begin{tabular}{|c|c|c|c|c|c|c|c|c|c|c|}
\hline \multirow{2}{*}{ Sample } & \multicolumn{10}{|c|}{ Composition (\%) } \\
\hline & $\mathbf{N a}$ & Mg & Al & Si & $\mathbf{K}$ & $\mathbf{C a}$ & $\mathbf{T i}$ & $\mathbf{F e}$ & Cd & $\mathbf{P b}$ \\
\hline Fluidgel & 4.05 & 4.07 & 16.33 & 55.27 & 0.59 & 5.08 & 1.08 & 13.50 & 0 & 0 \\
\hline Fluidgel TA & 0.67 & 4.02 & 19.53 & 64.12 & 0.56 & 2.05 & 0.91 & 8.14 & 0 & 0 \\
\hline Fluidgel TACal & 3.08 & 3.52 & 15.31 & 64.20 & 0.55 & 2.70 & 1.06 & 9.58 & 0 & 0 \\
\hline Fluidgel TA + Pb & 0 & 4.24 & 19.64 & 58.06 & 0.36 & 1.86 & 0.75 & 13.68 & 0 & 1.39 \\
\hline Fluidgel TA + Cd & 0 & 4.33 & 20.94 & 64.18 & 0.39 & 1.39 & 0.84 & 6.37 & 1.54 & 0 \\
\hline $\begin{array}{l}\text { Fluidgel } \\
\text { TACal }+\mathrm{Pb}\end{array}$ & 0.12 & 4.59 & 13.74 & 62.52 & 0.29 & 1.47 & 1.02 & 13.04 & 0 & 2.84 \\
\hline
\end{tabular}






(a)

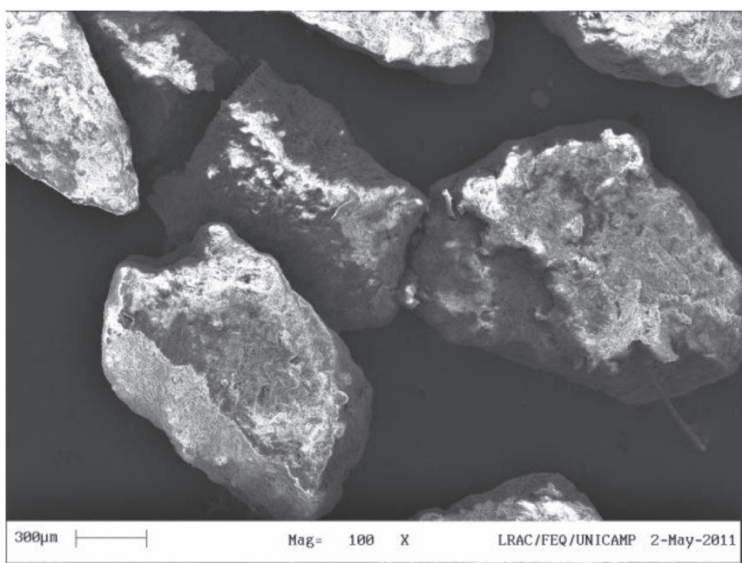

(b)

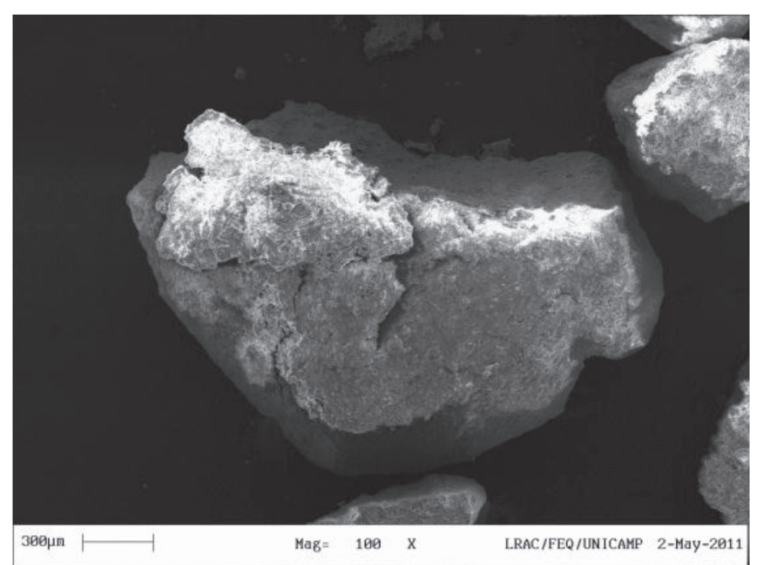

(c)

Figure 3. SEM image for Fluidgel (a); Fluidgel TA-bentonite (b) and Fluidgel TACal-bentonite (c).

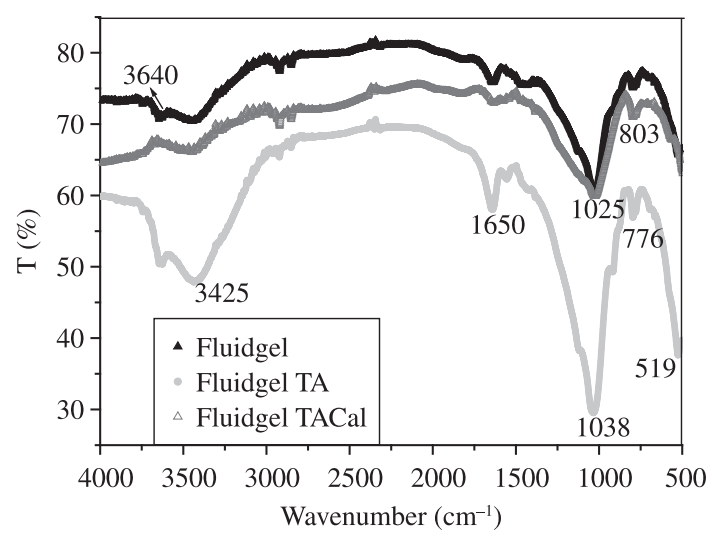

Figure 4. FTIR spectra for: Fluidgel, Fluidgel TA-bentonite and Fluidgel TACal-bentonite.

the CEC was estimated by assuming the displacement of sodium ions by ammonium ions, knowing that the industrial treatment with sodium ions did not replace calcium or potassium.
The cation exchange capacity values obtained for Fluidgel clay was of $171.74 \mathrm{mEq} .(100 \mathrm{~g})^{-1}$, being for Fluidgel TA-bentonite $60.98 \mathrm{mEq} .(100 \mathrm{~g})^{-1}$ and finally to Fluidgel TACal-bentonite $32.914 \mathrm{mEq} .(100 \mathrm{~g})^{-1}$. The results showed that the cation exchange capacity decreased dramatically with acid and heat treatment, accordingly to the results reported by other works ${ }^{37-40}$. These results did not prevent adsorption process of lead and cadmium onto bentonite, since the ion exchange is not the only mechanism here involved.

\section{Adsorption of Lead and Cadmium}

The adsorption of $\mathrm{Cd}(\mathrm{II})$ and $\mathrm{Pb}(\mathrm{II})$ has been thoroughly studied in batch system onto Fluidgel TA-bentonite as well as Fluidgel TACal-bentonite. The Fluidgel was not used because its $\mathrm{pH}$ occasioned chemical precipitation.

Fluidgel TA-bentonite: The kinetic tests were performed using monocomponent solutions containing $\mathrm{Cd}^{2+}$ and $\mathrm{Pb}^{2+}$ ions at $0.394 \mathrm{mmol} . \mathrm{L}^{-1}$. The adsorption kinetics curves are shown in Figure 5a, b. Adsorption process of cadmium and lead ions into pores of clays occurred rapidly at the first moments. Equilibrium was reached in 150 minutes for $\mathrm{Cd}^{2+}$ 


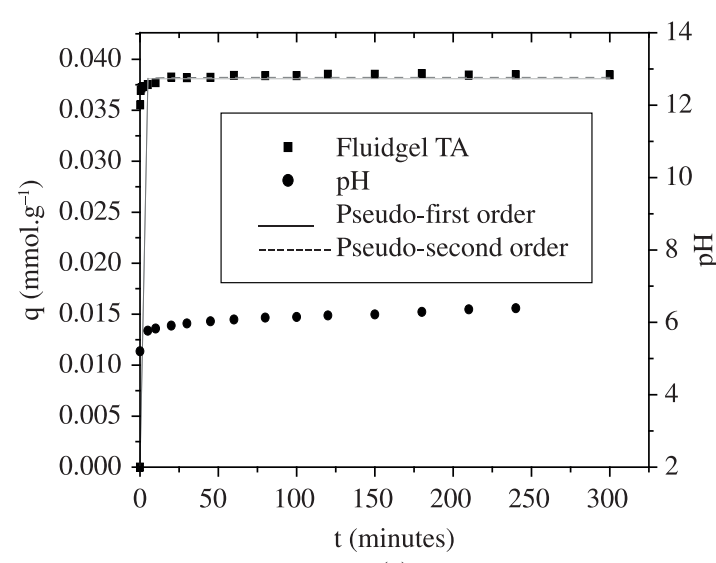

(a)

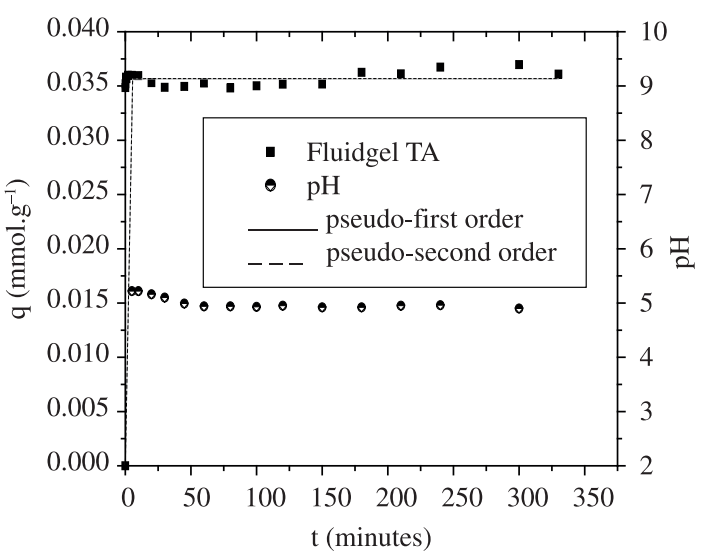

(b)

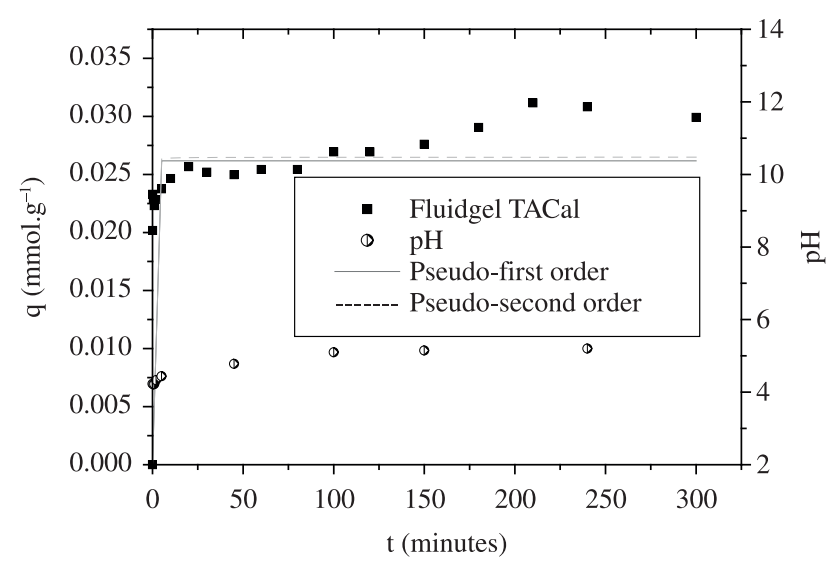

(c)

Figure 5. Kinetic curves of removal of $\mathrm{Cd} 2+$ (a) and $\mathrm{Pb} 2+$ (b) onto Fluidgel TA-bentonite and $\mathrm{Pb} 2+$ onto Fluidgel TACAl-bentonite (c)

and 250 minutes $\mathrm{Pb}^{2+}$. The maximum amount removed for cadmium was of 0.038 and for lead $0.035 \mathrm{mmol} . \mathrm{g}^{-1}$. The ion exchange can be an additional process for removal of cadmium and lead onto Fluidgel TA-bentonite, being verified by results of chemical composition presented in Table 2 , where the percentage of exchangeable sodium in the clay after adsorption drastically decreased. The mechanism of ion exchange can be written as follows:

$$
\begin{aligned}
& 2 \mathrm{Na}^{+}-\mathrm{Clay}+\mathrm{Pb}^{2+} \rightarrow \mathrm{Pb}^{2+}-\mathrm{Clay}+2 \mathrm{Na}^{+} \\
& 2 \mathrm{Na}^{+}-\text {Clay }+\mathrm{Cd}^{2+} \rightarrow \mathrm{Cd}^{2+}-\mathrm{Clay}+2 \mathrm{Na}^{+}
\end{aligned}
$$

The linear correlation coefficients and pseudo-first-order constants $\left(\mathrm{k}_{1}\right)$ and second-order constants $\left(\mathrm{k}_{2}\right)$ as well as the equilibrium capacity obtained in Figure 5 are shown in Table 4. In order to determine the equation that best describes the adsorption of $\mathrm{Cd}$ and $\mathrm{Pb}$, other statistical parameters such as reduced chi-square $\left(\mathrm{x}^{2}\right)$ and root mean square error $\left(\mathrm{E}_{\mathrm{RMS}}\right)$ values were calculated (Table 4). The intraparticle diffusion constants $\left(\mathrm{k}_{\mathrm{i}}\right)$ obtained in Figure 6 are reported in Table 4.

The pseudo-first-order and pseudo-second-order models presented good fits for all adsorption kinetic curves as shown by the coefficients of determination in Table 3 . However it can be observed that pseudo second order model presented the highest $\mathrm{R}^{2}$, the lowest $\mathrm{X}^{2}$ and $\mathrm{E}_{\mathrm{RMS}}$ values approach to zero, which indicated a better fit to adsorption kinetic.
Figure 6a, b show amount of heavy metals adsorbed per unit mass of adsorbent, $\mathrm{q}$ versus $\mathrm{t}^{1 / 2}$ for $\mathrm{Cd}$ (II) and $\mathrm{Pb}$ (II) adsorption. The value of $\mathrm{k}_{\mathrm{i}}$ obtained varied from 0.45 to 20 minutes for diffusion kinetics of cadmium onto Fluidgel TA-bentonite clay. The coefficient of determination $\mathrm{R}^{2}$ was $\left(\mathrm{R}^{2}>0.95\right)$, indicating that the intra-particle diffusion in the second phase is a limiting step. According to the results for $\mathrm{Pb}^{2+}$ (Figure 6b), it can be seen that intra-particle diffusion is not the rate-limiting step in the adsorption process, being observed only two phases: the instantaneous diffusion and equilibrium stage. Therefore, it was not possible to obtain the parameter of gradual intra-particle diffusion for the sorption of $\mathrm{Pb}^{2+}$.

Fluidgel TACal-bentonite: The kinetic tests were performed using monocomponent solutions containing $\mathrm{Cd}^{2+}$ and $\mathrm{Pb}^{2+}$ ions at a concentration of $0.394 \mathrm{mmol} . \mathrm{L}^{-1}(44.3 \mathrm{ppm})$ and of 0.178 (36.93 ppm), respectively. The kinetic curve of lead removal is shown on Figure 5c. Adsorption process of cadmium and lead ions into pores of clays also occurred rapidly at the first moments; however the removal capacity reduced due to thermal treatment, which was verified by other work ${ }^{16}$. The maximum amount removed for lead was of $0.033 \mathrm{mmol}$ metal. $\mathrm{g}^{-1}$ clay while for cadmium was not significant $\left(0.005\right.$ mmol. $\left.\mathrm{g}^{-1}\right)$, for this reason its kinetic curve was not shown.

In the Table 3 are reported coefficients of determination. The pseudo-first order and pseudo-second order models cannot 
be fitted to experimental data onto Fluidgel TACal-bentonite, resulting in lower values of coefficients $\mathrm{R}^{2}$ compared with those obtained for the clay Fluidgel TA-bentonite.

The kinetics of intra-particle diffusion $\left(\mathrm{Pb}^{2+}\right)$ in the clay Fluidgel TACal-bentonite (Figure 6c), presents two stages of diffusion, an instantaneous adsorption stage and a second sloping linear portion, which indicates the gradual adsorption stage. The equilibrium point was not reached. The coefficients of determination $\mathrm{R}^{2}$ was 0.95 , indicating that the intra-particle diffusion in the second phase is a limiting step.

\subsection{Adsorption equilibrium}

Fluidgel TA-bentonite: To identify the mechanism of the adsorption process, the adsorption of $\mathrm{Cd}^{2+}$ and $\mathrm{Pb}^{2+}$

Table 3. Pseudo-first and second order kinetic parameters for the sorption of $\mathrm{Cd}(\mathrm{II})$ and $\mathrm{Pb}$ (II) onto Fluidgel TA- bentonite clay and $\mathrm{Cd}(\mathrm{II})$ and $\mathrm{Pb}$ (II) onto Fluidgel TACal-bentonite clay.

\begin{tabular}{|c|c|c|c|c|c|c|c|c|c|c|}
\hline \multirow[b]{2}{*}{ System } & \multicolumn{5}{|c|}{ Pseudo-first order } & \multicolumn{5}{|c|}{ Pseudo-second order } \\
\hline & $\underset{\left(\text { mmol.g }^{-1}\right)}{q_{e}}$ & $\begin{array}{c}\mathbf{k}_{1} \\
\left(\mathbf{m i n}^{-1}\right)\end{array}$ & $\mathbf{R}^{2}$ & $\mathbf{X}^{2}$ & $\mathbf{E}_{\text {RMS }}$ & $\underset{\left(\mathrm{mmol}_{\mathrm{e}} \mathrm{g}^{-1}\right)}{\mathrm{q}_{\mathrm{e}}}$ & $\begin{array}{c}\mathrm{k}_{2} \\
\left(\mathrm{mmol}^{-1} \cdot \mathrm{min}^{-1}\right)\end{array}$ & $\mathbf{R}^{2}$ & $\mathbf{X}^{2}$ & $\mathbf{E}_{\mathrm{RMS}}$ \\
\hline $\begin{array}{l}\text { Fluidgel } \\
\mathrm{TA}+\mathrm{Cd}\end{array}$ & 0.03 & 16.13 & 0.996 & $1.55 \times 10^{-7}$ & $3.6 \times 10^{-4}$ & 0.04 & 70.70 & 0.998 & $8.9 \times 10^{-8}$ & $2.8 \times 10^{-4}$ \\
\hline $\begin{array}{l}\text { Fluidgel } \\
\mathrm{TA}+\mathrm{Pb}\end{array}$ & 0.03 & 23.13 & 0.994 & $5.23 \times 10^{-7}$ & $6.7 \times 10^{-4}$ & 0.03 & 86.22 & 0.991 & $7.3 \times 10^{-3}$ & $8.2 \times 10^{-2}$ \\
\hline $\begin{array}{c}\text { Fluidgel } \\
\mathrm{TACal}+\mathrm{Cd}\end{array}$ & $4.0 \times 10^{-3}$ & 9.55 & 0.801 & $3.56 \times 10^{-7}$ & $5.3 \times 10^{-4}$ & $4.5 \times 10^{-3}$ & 13.79 & 0.862 & $2.66 \times 10^{-7}$ & $4.9 \times 10^{-4}$ \\
\hline $\begin{array}{c}\text { Fluidgel } \\
\text { TACal + Pb }\end{array}$ & 0.02 & 16.49 & 0.844 & $8.39 \times 10^{-6}$ & $2.4 \times 10^{-3}$ & 0.03 & 32.52 & 0.867 & $5.93 \times 10^{-6}$ & $2.3 \times 10^{-3}$ \\
\hline
\end{tabular}

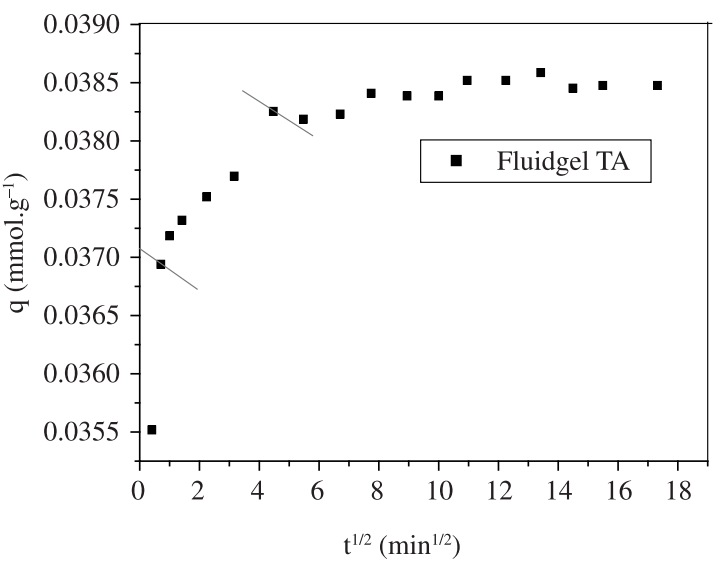

(a)

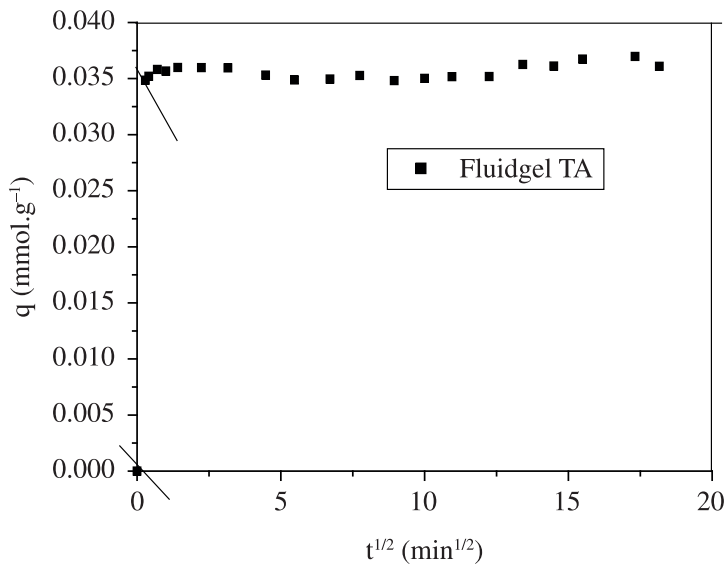

(b)

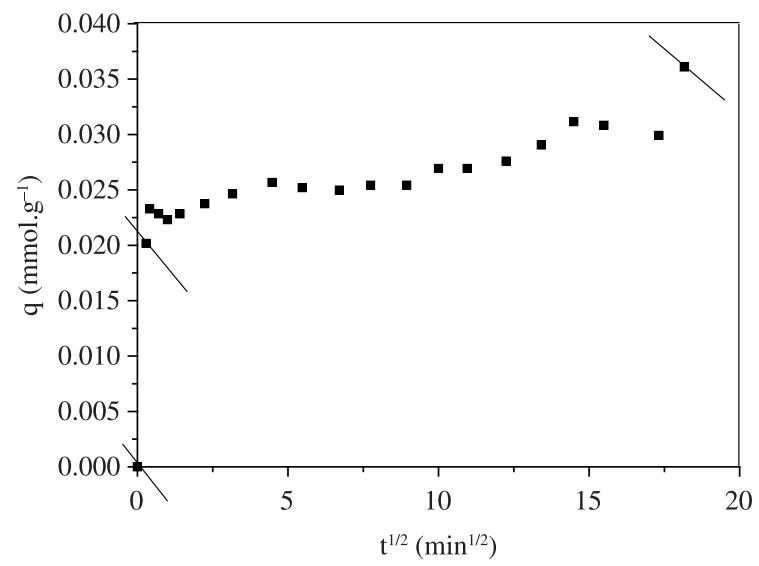

(c)

Figure 6. Sorption of $\mathrm{Cd}^{2+}$ (a) and $\mathrm{Pb}^{2+}$ (b) onto Fluidgel TA-bentonite and sorption of $\mathrm{Pb}^{2+}$ onto Fluidgel TACal-bentonite (c) as a function of square root of time for intra-particle diffusion rate constant determination. 
on Fluidgel TA-bentonite is determined as a function of equilibrium concentrations and the corresponding adsorption isotherms are plotted in Figure 7a, b. The isotherm constants calculated using Langmuir and Freundlich models are summarized in Table 5.

Table 4. Parameters of intra-particle diffusion for the sorption of $\mathrm{Cd}(\mathrm{II})$ and $\mathrm{Pb}$ (II) onto Fluidgel TA-bentonite clay and $\mathrm{Cd}(\mathrm{II})$ and $\mathrm{Pb}$ (II) onto Fluidgel TACal-bentonite clay.

\begin{tabular}{|c|c|c|c|}
\hline \multirow[b]{2}{*}{ System } & \multicolumn{3}{|c|}{ Intra-particle diffusion } \\
\hline & $\begin{array}{c}\mathrm{K}_{\mathrm{i}} \\
\left(\mathrm{mmol}^{-1} \mathrm{~min}^{-1 / 2}\right)\end{array}$ & $\begin{array}{c}c \\
\text { cmmol.g-1) }\end{array}$ & $\mathbf{R}^{2}$ \\
\hline $\begin{array}{l}\text { Fluidgel } \\
\mathrm{TA}+\mathrm{Cd}\end{array}$ & $9 \times 10^{-4}$ & 0.03 & 0.96 \\
\hline $\begin{array}{c}\text { Fluidgel } \\
\text { TACal + Cd }\end{array}$ & $3.43 \times 10^{-4}$ & $2.0 \times 10^{-3}$ & 0.97 \\
\hline $\begin{array}{c}\text { Fluidgel } \\
\mathrm{TACal}+\mathrm{Pb}\end{array}$ & $5.47 \times 10^{-4}$ & 0.02 & 0.95 \\
\hline
\end{tabular}

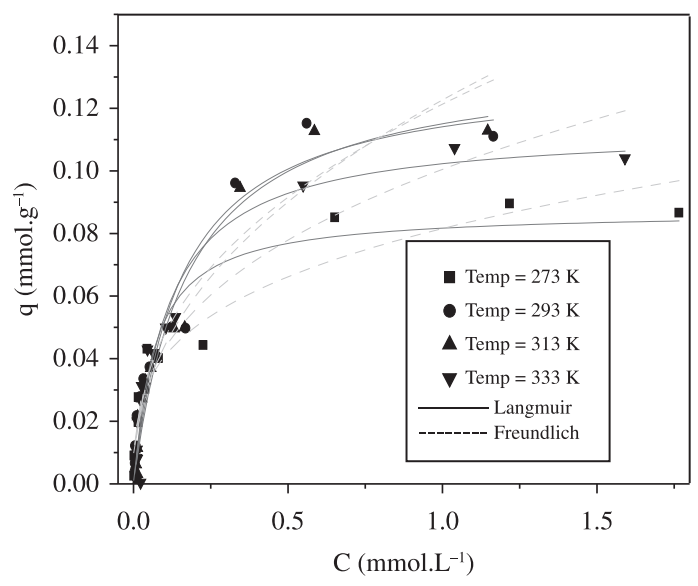

(a)
In Table 5 are reported coefficients of determination for the adsorption of $\mathrm{Cd}^{2+}$ and $\mathrm{Pb}^{2+}$. The process was well represented by Langmuir and Freundlich models. The maximum adsorption capacity of $\mathrm{Pb}^{2+}\left(\mathrm{q}_{\max }\right)$ and constant $\mathrm{b}$ obtained by Langmuir fit increased with the increase of the temperature (293-333 K). In contrast, the adsorption capacity of $\mathrm{Cd}^{2+}$ did not significantly change with increasing the temperature, which means that, the removal of cadmium by clay Fluidgel TA-bentonite is exothermic. The $\mathrm{R}_{\mathrm{L}}$ values obtained in this work (data not shown) varied in the range of $0<\mathrm{R}_{\mathrm{L}}<1$, indication of favorable adsorption.

Fluidgel TACal-bentonite: Figure 7c shows isotherm plots obtained on the adsorption process of $\mathrm{Pb}^{2+}$ on Fluidgel TACal-bentonite. The isotherm constants are also summarized in Table 5. The maximum adsorption capacity was obtained to $333 \mathrm{~K}$. However, above this value, an increase in the temperature has no effect on the adsorption capacity of the lead. From the results for adsorption of lead we can be established that the affinity of $\mathrm{Pb}^{2+}$ onto Fluidgel TA-bentonite is greater than $\mathrm{Pb}^{2+}$ onto Fluidgel TACal-bentonite.

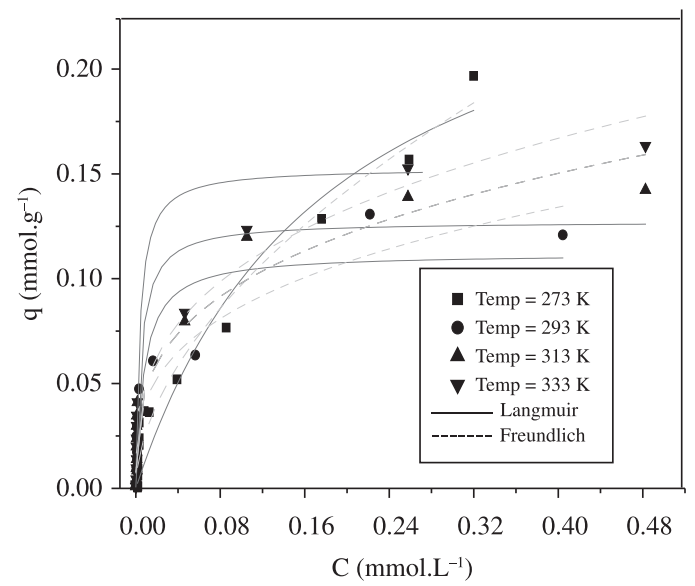

(b)

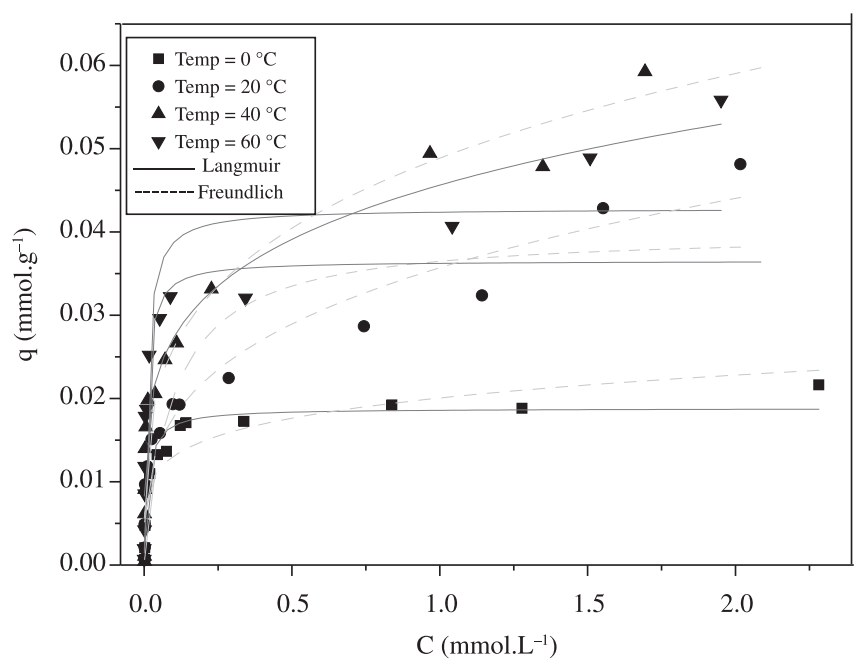

(c)

Figure 7. Adsorption isotherms of $\mathrm{Cd}^{2+}$ ions (a) and $\left(\mathrm{Pb}^{2+}\right)$ (b) onto Fluidgel TA-bentonite and adsorption isotherms of $\mathrm{Pb}^{2+}$ onto Fluidgel TACal-bentonite (c). 
Table 5. Langmuir and Freundlich isotherm constants and correlation coefficients.

\begin{tabular}{|c|c|c|c|c|c|c|}
\hline \multirow[b]{2}{*}{ System } & \multicolumn{3}{|c|}{ Langmuir } & \multicolumn{3}{|c|}{ Freundlich } \\
\hline & $\underset{\left(\mathrm{mmol}^{-\mathrm{g}^{-1}}\right)}{\mathbf{q}_{\max }}$ & $\begin{array}{c}\text { b } \\
\left(\mathbf{L} \cdot \mathrm{g}^{-1}\right)\end{array}$ & $\mathbf{R}^{2}$ & $\begin{array}{c}K \\
\left(\mathbf{L} \cdot \mathrm{g}^{-1}\right)^{1-\mathrm{n}}\end{array}$ & $\mathbf{n}$ & $\mathbf{R}^{2}$ \\
\hline Temperature (K) & \multicolumn{6}{|c|}{ Cadmium/Fluidgel TA } \\
\hline 273 & $8.7 \times 10^{-2}$ & 14.80 & 0.91 & 0.08 & 0.30 & 0.94 \\
\hline 293 & 0.13 & 7.68 & 0.96 & 0.12 & 0.40 & 0.92 \\
\hline 313 & 0.13 & 0.35 & 0.97 & 0.12 & 0.44 & 0.92 \\
\hline \multirow[t]{2}{*}{333} & 0.11 & 8.82 & 0.95 & 0.10 & 0.37 & 0.90 \\
\hline & \multicolumn{6}{|c|}{ Lead/Fluidgel TA } \\
\hline 273 & 0.28 & 5.40 & 0.94 & 0.34 & 0.55 & 0.98 \\
\hline 293 & 0.11 & 126.25 & 0.85 & 0.18 & 0.31 & 0.91 \\
\hline 313 & 0.13 & 198.53 & 0.93 & 0.20 & 0.31 & 0.94 \\
\hline \multirow[t]{2}{*}{333} & 0.15 & 256.57 & 0.89 & 0.27 & 0.33 & 0.96 \\
\hline & \multicolumn{6}{|c|}{ Lead/Fluidgel TACal } \\
\hline 273 & $1.8 \times 10^{-2}$ & 79.91 & 0.94 & 0.02 & 0.19 & 0.84 \\
\hline 293 & $4.0 \times 10^{-2}$ & 10.27 & 0.83 & 0.04 & 0.31 & 0.96 \\
\hline 313 & $3.6 \times 10^{-2}$ & 115.39 & 0.87 & 0.05 & 0.28 & 0.95 \\
\hline 333 & $4.4 \times 10^{-2}$ & 95.26 & 0.89 & 0.05 & 0.22 & 0.91 \\
\hline
\end{tabular}

Table 6. Thermodynamic parameters for the sorption processes of $\mathrm{Cd}(\mathrm{II})$ and $\mathrm{Pb}(\mathrm{II})$ onto Fluidgel TA-bentonite and Fluidgel TACalbentonite clays.

\begin{tabular}{|c|c|c|c|}
\hline System & $\Delta \mathbf{H}\left(\mathbf{K J} . \mathrm{mol}^{-1}\right)$ & $\Delta \mathbf{S}\left(\mathrm{J} \cdot \mathrm{mol}^{-1} \cdot \mathbf{K}^{-1}\right)$ & $\Delta \mathbf{G}\left(\mathbf{K J} \cdot \mathrm{mol}^{-1}\right)$ \\
\hline $\begin{array}{c}\text { Temperature } \\
\text { (K) }\end{array}$ & \multicolumn{3}{|c|}{ Cadmium/Fluidgel TA } \\
\hline 273 & \multirow{4}{*}{-6.65} & \multirow{4}{*}{-1.05} & -6.34 \\
\hline 293 & & & -6.43 \\
\hline 313 & & & -6.17 \\
\hline \multirow[t]{2}{*}{333} & & & -6.37 \\
\hline & \multicolumn{3}{|c|}{ Lead/Fluidgel TA } \\
\hline 273 & \multirow{4}{*}{14.33} & \multirow{4}{*}{87.52} & -9.81 \\
\hline 293 & & & -10.90 \\
\hline 313 & & & -12.97 \\
\hline \multirow[t]{2}{*}{333} & & & -15.05 \\
\hline & \multicolumn{3}{|c|}{ Lead/Fluidgel TACal } \\
\hline 273 & \multirow{4}{*}{11.74} & \multirow{4}{*}{66.93} & -6.55 \\
\hline 293 & & & -8.03 \\
\hline 313 & & & -8.74 \\
\hline 333 & & & -10.83 \\
\hline
\end{tabular}

The cadmium removal by Fluidgel TACal clay did not occurred.

\subsection{Adsorption thermodynamics}

The thermodynamic parameters such as change in enthalpy $(\Delta \mathrm{H})$, change in entropy, $(\Delta \mathrm{S})$ and change in Gibbs free energy $(\Delta \mathrm{G})$ obtained for the adsorption of $\mathrm{Cd}^{2+}$ and $\mathrm{Pb}^{2+}$ at different temperatures onto Fluidgel TA and Fluidgel TACal clay adsorbent are given in Table 6 .

The negative values of both $\Delta \mathrm{H}$ and $\Delta \mathrm{S}$ indicate an exothermic reaction during the adsorption of $\mathrm{Cd}^{2+}$ onto Fluidgel TA, whereas negatives values of $\Delta \mathrm{G}$ values for cadmium and lead by Fluidgel TA-bentonite and Fluidgel TACal-bentonite indicate a spontaneous adsorption process. The value of $\Delta \mathrm{H}$ was found $<40 \mathrm{~kJ}^{\mathrm{m}} \mathrm{mol}^{-1}$ for all cases onto the two clays, suggesting that the adsorption is physical with electrostatic interaction between sorption sites and the metal ion ${ }^{41}$.

On the other hand for $\mathrm{Pb}^{2+}$ ions, the change in enthalpy values $(\Delta \mathrm{H})$ is positive, showing that the sorption of $\mathrm{Pb}^{2+}$ on Fluidgel TA-bentonite and Fluidgel TACal-bentonite is endothermic in nature. It can be observed that $\Delta \mathrm{G}$ values obtained for $\mathrm{Cd}^{2+}$ and $\mathrm{Pb}^{2+}$ were found to be negative indicating that the adsorption of both metal ions onto Fluidgel TA-bentonite and also Fluidgel TACal-bentonite clays were spontaneous. Thus, the positive $\Delta \mathrm{S}\left(\mathrm{Pb}^{2+}\right)$ value represents the rise of randomness in the interface between the solid and the solution during the fixation of $\mathrm{Pb}^{2+}$ on the active sites of the adsorbent ${ }^{20}$. It can be seen that adsorption of $\mathrm{Cd}^{2+}$ has a negative $\Delta \mathrm{S}$ suggesting some structural changes in the clay and adsorbate ${ }^{42}$.

\section{Conclusions}

The basal spacing characteristic peaks $\left(\mathrm{d}_{001}\right)$ presented structural change due to thermal and chemical treatments. Pseudo-second order model presented the highest $\mathrm{R}^{2}$ and the lowest $\mathrm{x}^{2}$ and $\mathrm{E}_{\mathrm{RMS}}$ values approach to zero, indicating a better fit to adsorption kinetic for cadmium and lead ions onto Fluidgel TA-bentonite. The mechanism of ion exchange was considered part of the adsorption process onto Fluidgel TA-bentonite, considering the decrease of sodium percentage in the chemical composition of clay after process. The maximum removal efficiencies were $97.62 \%$ for Cd(II) using Fluidgel TA-bentonite and $91.08 \%$ for lead by Fluidgel TACal-bentonite modified chemical and thermally. The results also showed that Fluidgel TA and Fluidgel TACal clays can be used as alternative adsorbents for the removal of $\mathrm{Pb}^{2+}$ ions, due to its adsorptive properties. 
The adsorption capacity of $\mathrm{Pb}^{2+}$ increased with the increase of the temperature, indicating an endothermic process. The adsorption of $\mathrm{Cd}^{2+}$ by Fluidgel TA-bentonite provided a negative $\Delta \mathrm{S}$ value demonstrating a more stable formation of Fluidgel-TA-bentonite- $\mathrm{Cd}^{2+}$ complex. The adsorption of $\mathrm{Pb}^{2+}$ presented a positive $\Delta \mathrm{S}$ for both clays, which suggest a structural change in the adsorbent and adsorbate after adsorption. The $\Delta \mathrm{G}$ values in the adsorption process of both

\section{References}

1. Ahmedna M, Marshall WE, Husseiny AA, Rao RM and Goktepe I. The use of nutshell carbons in drinking water filters for removal of trace metals. Water Research. 2004; 38(4):1062-1068. http:// dx.doi.org/10.1016/j.watres.2003.10.047

2. Kang SY, Lee JU, Moon SH and Kim KW. Competitive adsorption characteristics of $\mathrm{Co}^{2+}, \mathrm{Ni}^{2+}$, and $\mathrm{Cr}^{3+}$ by IRN-77 cation exchange resin in synthesized, wastewater. Chemosphere. 2004; 56(2):141-147. http://dx.doi. org/10.1016/j.chemosphere.2004.02.004

3. Mohsen-Nia M, Montazeri P and Modarress H. Removal of $\mathrm{Cu}^{2+}$ and $\mathrm{Ni}^{2+}$ from waste water with a chelating agent and reverse osmosis processes. Desalination. 2007; 217(1-3):276-281. http://dx.doi.org/10.1016/j.desal.2006.01.043

4. Charerntanyarak L. Heavy metals removal by chemical coagulation and precipitation. Water Science and Technology. 1999; 39(10-11):135-138. http://dx.doi. org/10.1016/S0273-1223(99)00304-2

5. Landáburu-Aguirre J, García V, Pongrácz E and Keiski RL. The removal of zinc from synthetic wastewaters by micellar-enhanced ultrafiltration: statistical design of experiments. Desalination. 2009; 240(1-3):262-269. http:// dx.doi.org/10.1016/j.desal.2007.11.077

6. Jiang MQ, Jin XY, Lu X and Chen ZL. Adsorption of $\mathrm{Pb}(\mathrm{II}), \mathrm{Cd}(\mathrm{II}), \mathrm{Ni}(\mathrm{II})$ and $\mathrm{Cu}(\mathrm{II})$ onto natural kaolinite clay. Desalination. 2010; 252(1-3):33-39. http://dx.doi. org/10.1016/j.desal.2009.11.005

7. Adebowale KO, Emmanuel EI and Olu-Owolabi BI. Kinetic and thermodynamic aspects of the adsorption of $\mathrm{Pb}^{2+}$ and $\mathrm{Cd}^{2+}$ ions on tripolyphosphate-modified kaolinite clay. Chemical Engineering Journal. 2008; 136(2-3):99-107. http://dx.doi. org/10.1016/j.cej.2007.03.012

8. Jusoh A, Shiung LS, Ali N and Noor MJMM. A simulation study of the removal efficiency of granular activated carbon on cadmium and lead. Desalination. 2007; 206(1-3):9-16. http:// dx.doi.org/10.1016/j.desal.2006.04.048

9. Gupta SS and Bhattacharyya KG. Removal of Cd(II) from aqueous solution by kaolinite, montmorillonite and their poly (oxo zirconium) and tetrabutylammonium derivatives. Journal of Hazardous Materials. 2005; 128(2-3):247-257. http://dx.doi. org/10.1016/j.jhazmat.2005.08.008

10. Ouki SK and Kavannagh M. Treatment of metals-contaminated wastewaters by use of natural zeolites. Water Science and Technology. 1999; 39(10-11):115-122. http://dx.doi. org/10.1016/S0273-1223(99)00260-7

11. Vieira MGA, Almeida Neto AF, Silva MGC, Carneiro CN and Melo Filho AA. Characterization and use of in natura and calcined rice husks for biosorption of heavy metals ions from aqueous effluents. Brazilian Journal of Chemical Engineering. 2012; 29(3):619-633. http://dx.doi.org/10.1590/ S0104-66322012000300019
$\mathrm{Cd}^{2+}$ and $\mathrm{Pb}^{2+}$ ions by Fluidgel TA-bentonite and Fluidgel TACAl-bentonite clay were found to be negative, which suggests that adsorption of cadmium and lead onto these clays is spontaneous in nature.

\section{Acknowledgements}

\section{FAPESP, FAEPEX and CNPq.}

12. Vieira MGA, Almeida Neto AF, Gimenes ML and Silva MGC. Sorption kinetics and equilibrium for the removal of nickel ions from aqueous phase on calcined Bofe bentonite clay. Journal of Hazardous Materials. 2010; 177(1-3):362-371. http://dx.doi. org/10.1016/j.jhazmat.2009.12.040

13. Abollino O, Aceto M, Malandrino M, Sarzanini C and Mentasti E. Adsorption of heavy metals on Na-montmorillonite. Effect of pH and organic substances. Water Reseach. 2003; 37(7):16191627. http://dx.doi.org/10.1016/S0043-1354(02)00524-9

14. Murray HH. Applied Clay Mineralogy: Occurrences, Processing and Application of Kaolins, Bentonites, Palygorskite-Sepiolite, and Common Clays. Elsevier B.V, 2006.

15. Chagas AP. Argilas: As essências da terra. São Pablo: Moderna, 1996.

16. Almeida Neto AF, Vieira MGA, Silva MGC. Cu(II) adsorption on modified bentonitic clays: different isotherm behaviors in static and dynamic systems. Materials Research. 2012; 15(1):114-124. http://dx.doi.org/10.1590/ S1516-14392011005000089

17. Bertagnolli C, Kleinübing SJ, Silva MGC. Preparation and characterization of a Brazilian bentonite clay for removal of copper in porous beds. Applied Clay Science. 2011; 53(1):73-79. http://dx.doi.org/10.1016/j.clay.2011.05.002

18. Karapinar $\mathrm{N}$ and Donat R. Adsorption behavior of $\mathrm{Cu}^{2+}$ and $\mathrm{Cd}^{2+}$ onto natural bentonite. Desalination. 2009; 249(1):123-129. http://dx.doi.org/10.1016/j.desal.2008.12.046

19. Inglezakisa VJ, Stylianou MA, Gkantzoua D, Loizidoua MD. Removal of $\mathrm{Pb}$ (II) from aqueous solutions by using clinoptilolite and bentonite as adsorbents. Desalination. 2007; 210(1-3):248-256. http://dx.doi. org/10.1016/j.desal.2006.05.049

20. Huang R, Wang B, Yang B, Zheng D and Zhang Z. Equilibrium, kinetic and thermodynamic studies of adsorption of Cd(II) from aqueous solution onto HACC-bentonite. Desalination. 2011; 280(1):297-304. http://dx.doi. org/10.1016/j.desal.2011.07.033

21. Sari A, Tuzen M, Citak D and Soylak M. Equilibrium, kinetic and thermodynamic studies of adsorption of $\mathrm{Pb}$ (II) from aqueous solution onto Turkish kaolinite clay. Journal of Hazardous Materials. 2007; 283-291. http://dx.doi. org/10.1016/j.jhazmat.2007.03.078

22. Adebowale KO, Unuabonah EI and Olu-Owolabi IB. Kinetic and thermodynamic aspects of the adsorption of $\mathrm{Pb}^{2+}$ and $\mathrm{Cd}^{2+}$ ions on tripolyphosphate-modified kaolinite clay. Chemical Engineering Journal. 2008, 136(2-3):99-107. http://dx.doi. org/10.1016/j.cej.2007.03.012

23. Singha SP, Mab LQ, Hendrya MJ. Characterization of aqueous lead removal by phosphatic clay: Equilibrium and kinetic studies. Journal of Hazardous Materials. 2006, 136(3):654-662. http://dx.doi.org/10.1016/j.jhazmat.2005.12.047

24. Lange NA. Lange's Handbook of chemistry. New York: McGraw Hill; 1973. 
25. Rhodes CN and Brown DR. Structural characterisation and optimisation of acid-treated montmorillonite and high-porosity silica supports for $\mathrm{ZnCl}_{2}$ alkylation catalysts. Journal of the Chemical Society, Faraday Transactions. 1992; 88:2269-2274. http://dx.doi.org/10.1039/ft9928802269

26. Tomić ZP, Vesna PL, Babicc BM, Rogand JR and Makreskie P. Comparison of structural, textural and thermal characteristics of pure and acid treated bentonites from Aleksinac and Petrovac Serbia. Spectrochimica Acta Part A. 2011; 82:389-395. http:// dx.doi.org/10.1016/j.saa.2011.07.068

27. Novakovića T, Rožića L, Petrovića S and Rosićb A. Synthesis and characterization of acid-activated Serbian smectite clays obtained by statistically designed experiments. Chemical Engineering Journal. 2008; 137(2):436-442. http://dx.doi. org/10.1016/j.cej.2007.06.003

28. Cótica LF, Freitasa VF, Santosa IA, Barabachb M, Anaissib FJ, Miyaharab RY and Sarvezukc PWC. Cobalt-modified Brazilian bentonites: Preparation, characterization, and thermal stability. Applied Clay Science. 2011; 51(1-2):187-191. http://dx.doi. org/10.1016/j.clay.2010.10.033

29. Srodon J, Drits VA, McCarty DK, Hsieh JCC and Eberl DD. Quantitative X-ray diffraction analysis of clay-bearing rocks from random preparations. Clays Clay Mineral. 2001; 49(6):514-528. http://dx.doi.org/10.1346/ CCMN.2001.0490604

30. Sdiri A, HigashiY, Hatta T, Jamoussi F and Tase N. Mineralogical and spectroscopic characterization and potential environmental use of limestone from the Abiod formation, Tunisia. Environmental Earth Sciences. 2010; 61(6), 1275-1287. http:// dx.doi.org/10.1007/s12665-010-0450-5

31. Guo Z, Xu Y, Shi K, Tang Y, Wu W and Tao Z. Eu(III) adsorption/desorption on Na-bentonite: Experimental and modeling studies. Colloids and Surfaces A: Physicochemical and Engineering Aspects. 2009; 339(1-3):126-133. http:// dx.doi.org/10.1016/j.colsurfa.2009.02.007

32. Venaruzzo JL, Volzone C, Rueda ML and Ortiga J. Modified bentonitic clay minerals as adsorbents of $\mathrm{CO}, \mathrm{CO}_{2}$ and $\mathrm{SO}_{2}$ gases. Microporous and Mesoporous Materials. 2002; 56(1):73-80. http://dx.doi.org/10.1016/S1387-1811(02)00443-2
33. Suárez Barriosa M, Flores Gonzalez LV, Vicente Rodriguez MA and Martin Pozas JM. Acid activation of a palygorskite with $\mathrm{HCl}$ : Development of physico-chemical, textural and surface properties. Applied Clay Science. 1995; (10):247-258. http:// dx.doi.org/10.1016/0169-1317(95)00007-Q

34. Rompaey KV, Ranst EV, De Coninck F and Vindevogel N. Dissolution characteristics of hectorite in inorganic acids. Applied Clay Science. 2002; (21):241-256. http://dx.doi. org/10.1016/S0169-1317(02)00086-8

35. Souza Santos P. Science and Technology of Clays. 2nd ed. São Pablo: Edgard Blücher Ltda; 1992.

36. Madejová J. FTIR techniques in clay mineral studies. Vibrational Spectroscopy. 2003; 31(1):1-10. http://dx.doi. org/10.1016/S0924-2031(02)00065-6

37. Didi AM, Makhoukhi B, Azzouz A and Villemin D. Colza oil bleaching through optimized acid activation of bentonite. A comparative study. Applied Clay Science. 2009; (42):336-344. http://dx.doi.org/10.1016/j.clay.2008.03.014

38. Christidis GE, Scott PW and Dunham AC. Acid activation and bleaching capacity of bentonites from the islands of Milos and Chios, Aegean, Greece. Applied Clay Science. 1997; (12):329-347. http://dx.doi.org/10.1016/ S0169-1317(97)00017-3

39. Prakash K, Raksh VJ and Thirumaleshwara SGB. Evolution of Porosity and Surface Acidity in Montmorillonite Clay on Acid Activation. Industrial \& Engineering Chemistry Research. 1995; (34):1140-1448.

40. Vieira MGA, Almeida Neto AF, Gimenes ML and Silva MGC. Removal of nickel on Bofe bentonite calcined clay in porous bed. Journal of Hazardous Materials, 176 (1-3):109-118. http:// dx.doi.org/10.1016/j.jhazmat.2009.10.128

41. Ghani A and Elchaghaby NT. Influence of operating conditions on the removal of $\mathrm{Cu}, \mathrm{Zn}, \mathrm{Cd}$ and $\mathrm{Pb}$ ion from wastewater by adsorption. International journal of Environmental Science and Technology. 2007; 4(4):451-456.

42. Manohar DM, Krishnan KA and Anirudhan TS. Removal of mercury (II) from aqueous solutions and chlor-alkali industry wastewater using 2-mercaptobenzimidazole-clay. Water Reseach. 2002; 36(6):1609-1619. http://dx.doi.org/10.1016/ S0043-1354(01)00362-1 


\section{Apendix 1. Nomenclature.}

$\mathrm{C}_{\mathrm{Na}}{ }^{+}$: concentration measured by atomic adsorption (mg. $\left.\mathrm{L}^{-1}\right)$

$\mathrm{C}_{0}$ : the initial concentration of metal ion in fluid phase $\left(\mathrm{mmol} . \mathrm{L}^{-1}\right)$

$\mathrm{C}(\mathrm{t})$ : the concentration of metal ion in solution at time $\mathrm{t}\left(\mathrm{mmol} . \mathrm{L}^{-1}\right)$

$\mathrm{q}_{\mathrm{e}}$ : amount of metal sorbed at equilibrium (mmol. $\left.\mathrm{g}^{-1}\right)$

$q$ : the concentration of the adsorbate in the solid phase $\left(\mathrm{mmol} . \mathrm{g}^{-1}\right)$

$\mathrm{b}, \mathrm{q}_{\mathrm{m}}$ : Langmuir coefficients, $\left(\mathrm{L}_{\mathrm{mmol}}{ }^{-1}\right)$ and $\left(\mathrm{mmol} . \mathrm{g}^{-1}\right)$, respectively

$\mathrm{C}$ : intra-particle diffusion model constant.

$\mathrm{C}_{\mathrm{e}}$ : concentration of metal ions in the liquid phases $\left(\mathrm{mmol} . \mathrm{L}^{-1}\right)$

$\mathrm{k}_{1}, \mathrm{k}_{2}$ : pseudo-first-order and second-order adsorption rate constant

$\mathrm{K}_{\mathrm{f}}$ and $\mathrm{n}$ : Freundlich coefficients

$\mathrm{K}_{\mathrm{i}}$ : intra-particle diffusion rate constant $\mathrm{m}$ mass of adsorbent $(\mathrm{g})$

$\mathrm{R}_{\mathrm{L}}$ : curvature of the sorption isotherm

$\mathrm{T}$ : temperature $(\mathrm{K})$

$\mathrm{V}$ : volume of solution $(\mathrm{mL})$

$\Delta \mathrm{G}$ : Gibbs free energy variation $\left(\mathrm{kJ} \cdot \mathrm{mol}^{-1}\right)$

$\Delta \mathrm{H}$ : enthalpy variation $\left(\mathrm{kJ} . \mathrm{mol}^{-1}\right)$

$\Delta \mathrm{S}$ : entropy variation $\left(\mathrm{J} . \mathrm{K}^{-1} \mathrm{~mol}^{-1}\right)$

$\mathrm{X}^{2}$ : reduced chi-square

ERMS: root mean square error

$\mathrm{q}_{\mathrm{ex}}$ : the concentration of the adsorbate in the solid phase obtained in the test (mmol.g $\mathrm{g}^{-1}$ )

$\mathrm{q}_{\mathrm{pre}}$ : the concentration of the adsorbate in the solid phase predicted. 